\title{
Sample Profitability and Cost Estimates of Producing Longan (Dimocarpus longan Lour.) in South Florida'
}

\author{
Fredy H. Ballen, Edward A. Evans, Aditya Singh, and Jonathan H. Crane ${ }^{2}$
}

\section{Introduction}

Longan (Dimocarpus longan) is a member of the soapberry family (Sapindaceae) and is native to southern Asia. It is an evergreen tree and possesses varied growth habits (spreading or erect) depending on the specific cultivar. Longan adapts well to tropical and subtropical climates with cool but nonfreezing winter temperatures. Longan is sometimes associated with lychee because of its similarity in structure but has a different flavor (Pham et al. 2016). The main world longan producers include China, Thailand, Vietnam, and Australia. Vietnam is the main exporter to the US market (Atlanta, Boston, and New York) and offers a year-round supply (USDA AMS 2017).

Longan was first introduced into the United States in 1903 from southern China (Morton 1987). Subsequently, during the 1940s, a significant amount of longan seeds were imported from China. US longan production is limited and restricted to Hawaii, California and Florida (Crane et. al. 2016). In Florida, climatic requirements of longan are particularly suited to the southern part of the state, and new longan plantings have increased over the past ten years to reach approximately 1,600 acres with the prospects of further expansion. About 90 percent of the longan production in Florida is in Miami-Dade County with the remaining acreage scattered in various south Florida counties (Palm Beach, Lee, Sarasota, etc.). Historically, longan was considered an unreliable bearer, and that limited expansion of the industry. However, with the discovery of the flower-inducing chemical potassium chlorate, growers can now improve flowering during the normal crop cycle (July-August) as well as produce off-season fruit; there is potential of year-round production (Crane 2010).

There are numerous cultivars of longan; however, worldwide only thirty to forty are grown commercially. In 1954, 'Kohala' a superior longan cultivar was introduced to south Florida from Hawaii (Morton 1987). About 99\% of the longan acreage in Florida is planted with 'Kohala'. A number of other cultivars including 'Edau' ('Daw'), 'Chompoo', and 'Biew Kiew' are planted to a limited extent by commercial growers. (Crane et al. 2016).

Assuming an average planting density of 87 trees per acre, an average yield of 250 pounds per tree, and a fruit packout rate of $83 \%$, marketable yield per acre is about 18,053 pounds. Florida total longan production is estimated at 28.9 million pounds.

The demand for longan in the United States is growing due to its promotion as a healthy food, its uses in ancient Chinese medicine (The Chalkboard 2013), and an increase in the Asian American population. This along with the ability to induce off-season flowering and harvests has resulted in a dramatic increase in Florida longan production. Longan from south Florida is generally sold to local and national Asian markets as fresh fruit. At an average "free on board"

1. This document is FE1049, one of a series of the Food and Resource Economics Department, UF/IFAS Extension. Original publication date January 2019. Visit the EDIS website at https://edis.ifas.ufl.edu for the currently supported version of this publication.

2. Fredy H. Ballen, data management analyst II; Aditya Singh, research scholar; Edward A. Evans, interim center director and professor; and Jonathan H. Crane, tropical fruit crop specialist; Food and Resource Economics Department; UF/IFAS Tropical Research and Education Center, Homestead, FL. 
(F.O.B) price (i.e., the price at the packinghouse) of $\$ 1.50$ / pound, the crop is worth $\$ 43.3$ million at the packinghouse level.

Given the growing interest in production costs and returns of minor tropical fruit crops, this publication provides an estimate of the costs and returns associated with the operation of an established longan grove in south Florida. Information presented in this article was obtained through field interviews with growers and industry experts; it reflects a wide variety of production practices in small longan orchards (1-4 acres). Therefore, the information provided here is intended only as a guide to estimate the financial requirements of operating an established longan grove. Readers interested in specific information about the cultural practices of longan may want to consult the EDIS document \#FC49 (Longan Growing in the Florida Home Landscape) and contact their local UF/IFAS Extension agent.

\section{Main Assumptions}

The budget and production cost items are based on a oneacre grove (on a per-year basis). Given the fact that tropical fruit growers in south Florida own the land, a rent cost of $\$ 500 /$ acre/year was used to account for the opportunity cost of the land. Because of the wide diversity of cultural and managerial practices found, average costs and returns are used for the present analysis.

Grove Layout-For the present analysis, we assume a longan planting distance of $20 \times 25 \mathrm{ft}$., resulting in a planting density of about 87 trees per acre.

Yields-Assuming a planting density of 87 trees per acre, an average yield from a mature tree ( 5 years and older) of about 250 pounds, and a fruit packing rate of $83 \%$, the average marketable yield is about 18,053 pounds per acre per year.

Longan Prices-The average F.O.B. price for longan in 2016 was estimated at $\$ 1.50$ per pound. This represents the average price the growers received from the packing houses in Homestead, Florida, for producing the crop, harvesting and transporting it to the packing house.

Irrigation-Once trees begin to bear fruit ( 5 years and older), they should be irrigated regularly from flowering through harvest for better yields and fruit quality (especially size). Average irrigation expenses comprising of fuel or electricity cost are estimated at $\$ 268 /$ acre/year.
Fertilization-For full-production longan trees, the fertilization program includes fertilizer containing low to moderate nitrogen content and low phosphate and high potash (N-P-K) content, soil drench applications of chelated iron, and foliar sprays of minor elements (Crane et al. 2016). One or more additional potash applications are warranted. Average fertilization expenses (materials cost only) are estimated at \$647/acre/year.

Pest Management-Longan has a few insect problems in south Florida. The most common pest is the lychee webworm, which attacks emerging shoots and young fruit, and, if left uncontrolled, diminishes crop yields. There are no major longan disease problems. A minor disease problem is the red alga (Cephaleuros virescens), which attacks limbs and shoots. Weed management consists of applications of mulch, which helps to suppress grass growth, and herbicide applications (Crane et al. 2016). Average agrochemicals materials cost is estimated as follows: insecticides cost \$286/acre/year, fungicides (mainly copper applications) cost \$235/acre and herbicides cost \$230/acre/year.

Labor Costs-Include agricultural inputs application costs like fertilizers, agrochemicals, and cultural operations like irrigation, pruning, mowing, removing vines, and other activities. A common cultural practice in longan is fruit thinning; after fruit set when longan fruit are about the size of a pea, the fruit-bearing panicle must be thinned to reduce the number of fruit per panicle to 50-75 fruit per panicle. If fruit are not thinned, fruit generally does not reach marketable size; thinning the panicle is labor intensive. Total labor costs are estimated at $\$ 779 /$ acre/year.

Interest on Operating Capital-This is the cost of borrowing money or the opportunity cost for using equity. A rate of five percent was used in the calculations. It is estimated at $\$ 122 /$ acre.

Fixed Costs-These are the costs incurred even if no fruit is produced. They include cash overhead, non-cash overhead, and other overhead costs. The cash overhead costs (e.g., insurance and taxes) are estimated at \$200/acre, and non-cash overhead costs (e.g., land rent) are estimated at about $\$ 500 /$ acre. Other overhead costs (e.g., machinery depreciation, interest, electricity, telephone, computer, and other office expenses) are estimated at \$567/acre.

Harvesting and Marketing Costs-Longan harvest season in south Florida runs from mid-July to early September with a peak in August. Harvesting season varies with cultivar for example, the main harvest season for the 'Kohala' cultivar spans from mid-July to August, whereas, for the 
'Edau' cultivar, the harvest season runs from late July to September. At maturity, the fruits are of an intense tan color and are harvested by hand or with the aid of pruning shears or a pole with a cutter (Crane et al. 2016). The annual cost for picking, packing, and marketing longan is estimated at $\$ 5,662$ /acre/year.

Table 1 shows the per-acre expenses and returns associated with a full-production longan grove

Production Costs or variable costs amounted to $\$ 2,567$ (about $\$ 0.14$ per pound), representing $27.03 \%$ of the total cost. The major cost components among the pre-harvest variable costs were hired labor (30\%), fertilizers (25\%), insecticide (11\%). and fungicides (9\%).

Fixed Costs include cash, non-cash, and other overhead charges (e.g., electricity, telephone), total fixed costs are estimated at $\$ 1,267 /$ acre/year ( $\$ 0.07 /$ pound), representing $13.34 \%$ of the total production cost. Although growers own the land, the prevailing market rate for land rental is used to reflect the opportunity cost of the land.

Harvest and Marketing Costs are estimated at \$5,662 ( $\$ 0.31$ per pound), and they represent $59.63 \%$ of the total cost. The main contributor to the harvest and marketing costs are the costs associated with picking, packing, and marketing of the fruit by the packinghouses. The longan fruit has an intense tan color during maturity stage and at this stage the fruit must be harvested. The fruit ripeness is indicated by pulp sweetness, which occurs before the fruit is removed from the tree (Crane et al. 2016).

The cost structure for longan production in south Florida and the respective share of its components are shown in figure 1. Harvest and marketing costs account for 59.63\% of the total cost, followed by cultural costs with a share of $25.75 \%$ of the total cost, fixed costs with $13.34 \%$ of the total cost, and interest on capital at $1.28 \%$ of the total cost.

\section{Returns and Profitability Analysis}

The information provided in Table 1 shows that the total cost to produce and market one acre of longan is estimated at $\$ 9,496 /$ acre or about $\$ 0.53$ per pound. Based on interviews with growers, average marketable yield is estimated at about 18,053 pounds per acre. Total receipt or gross revenue using the estimated packinghouse price of $\$ 1.50$ per pound is $\$ 27,080$ per acre. Subtracting operational and harvesting costs from total receipts gives the gross margin of $\$ 18,851$ ( $\$ 27,080-\$ 8,229)$ per acre $(\$ 1.04 / \mathrm{lb}$.). The gross margin provides a useful indicator of short-run profitability.
A positive gross margin implies that all variable costs have been covered by the income generated, and there are additional funds remaining to cover some or all of the fixed costs. A negative gross profit implies that a business is not viable in the short run, so changes are needed to make it viable. Most growers are only concerned with the gross margin. However, while the gross margin provides an indication of return to the grower, it does not include fixed costs, and hence is not a true reflection of the long-term profitability of the business.

Net Return is obtained by subtracting the fixed cost from the gross margin and is used to measure the long-term profitability of the farming operation. The data in Table1 show a net profit of $\$ 17,584$ per acre ( $\$ 0.97 / \mathrm{lb}$.).

\section{Sensitivity Analysis}

Table 2 presents a sensitivity analysis of gross margin (gross profit) to the grower that considers the short-term economic viability of a longan grove operation. Under the best-case scenario, where both price and yield are assumed to increase by $10 \%$, gross margin would increase from $\$ 18,851 /$ acre to $\$ 24,537 /$ acre. Under the worst-case scenario, where both price and yield decrease by $10 \%$, gross margin would decrease from $\$ 18,851$ /acre to $\$ 13,706$ / acre. Price changes (keeping the production constant) have a larger impact on gross return than quantity changes (keeping the price constant). It can be observed that a $5 \%$ increase in the base price (base yield 18,053 pounds) has a larger impact on gross return ( $\$ 1,444$ more) than a 5\% increase in yield (base price $\$ 1.50 /$ pound) ( $\$ 1,354$ more). It is important to remember that fixed costs are not taken into account when calculating gross margin (gross profit).

Table 3 presents a similar analysis conducted based on net returns. Under the best-case scenario where both price and yield are assumed to increase by $10 \%$, net return would increase from $\$ 17,584 /$ acre to $\$ 23,270 /$ acre. Under the worst-case scenario, where both price and yield decrease by $10 \%$, net return would decrease from $\$ 17,584$ /acre to $\$ 12,439 /$ acre. Other combinations of changes of prices and yields and their impact on net return are shown in Table 3. The information presented in table 3 can be interpreted in a similar way as it was presented for the Table 2. However, it should be noted that at the industry level, a perceptible increase in production usually results in a decrease in the price received by the growers.

\section{Concluding Remarks}

With a gross revenue of about $\$ 27,080 /$ acre $(\$ 1.5 / \mathrm{lb}$.), and net return to the grower of about $\$ 17,584 /$ acre, or $\$ 0.97 /$ 
lb., longan seems a very profitable alternative. The reader, however, is cautioned that the information presented in this article refers to an established grove and does not take into consideration the costs to establish the grove, such as landdevelopment costs, planting costs, and amortized capital costs. As mentioned earlier, the demand for longan in the United States is increasing and is expected to continue to do so as the popularity of the fruit and its health benefits become more widely known. At the same time, prospective growers are cautioned and should know that despite the growth in consumption, the market is still a niche one and, as such, can easily be oversupplied. Moreover, the main consumers of the crop (American Asians and Hispanics) are price sensitive; hence imports from low-cost producing countries like Vietnam pose a serious challenge for domestic producers (Federal Register 2014).

\section{Cost structure}

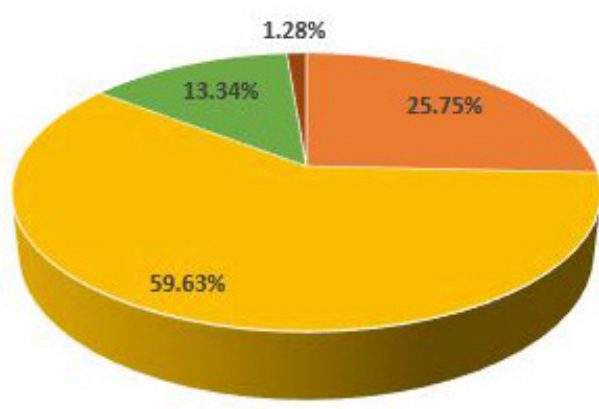

" Cultural costs "Harvest and marketing costs = Fixed costs "Interest on capital Figure 1. Proportion of costs.

\section{References}

Crane, J. H. 2010. How to Use Potassium Chlorate. Tropical Fruit Management Program. http://trec.ifas.ufl.edu/crane/ updates.shtml

Crane, J. H., C.F. Balerdi, S. A. Sargent, and I. Maguire. 2016. Longan growing in the Florida home landscape. FC49. Gainesville: University of Florida Institute of Food and Agricultural Sciences. http://edis.ifas.ufl.edu/mg049

Crane J.H., and M. Mossler. 2008. Crop Profile for Lychee and Longan in Florida. https://ipmdata.ipmcenters.org/ documents/cropprofiles/FLlycheeLongan2008.pdf

Federal Register. 2014. Importation of Litchi and Longan fruit from Vietnam into the continental United States. https://www.federalregister.gov/documents/2014/09/04/2014-21113/importation-of-litchi-andlongan-fruit-from-vietnam-into-the-continental-unitedstates
The chalkboard. 2013. Superfood spotlight: Longan fruit. http://thechalkboardmag.com/longan-fruit-superfood

Morton J. 1987. Fruits of warmer climates: Longan. https:// hort.purdue.edu/newcrop/morton/longan.html

Pham, V. T., M. Herrero, and J. I. Hormaza. 2016. "Fruiting pattern in longan, Dimocarpus longan: from pollination to aril development." Annals of Applied Biology 169 (3): 357-368.

USDA AMS. Terminal Market: Custom Reports https://www.marketnews.usda.gov/mnp/

fv-report-config-step 1 ?type $=$ termPrice 
Table 1. Sample budget for longan production (one acre).

\begin{tabular}{|c|c|c|c|}
\hline Item & Quantity (pounds) & $\begin{array}{c}\text { Value per acre (\$/acre/ } \\
\text { year) }\end{array}$ & $\begin{array}{l}\text { Value per pound ( } \$ / \\
\text { pound) }\end{array}$ \\
\hline \multicolumn{4}{|l|}{ Revenue } \\
\hline Marketable yield (lbs./acre) & 18,053 & & \\
\hline F.O.B. Homestead price & & & 1.50 \\
\hline Total revenue & & 27,080 & \\
\hline \multicolumn{4}{|l|}{ Production Costs } \\
\hline Irrigation & & 268 & \\
\hline Fertilizer & & 647 & \\
\hline Insecticide & & 286 & \\
\hline Fungicide & & 235 & \\
\hline Herbicide & & 230 & \\
\hline Labor cost & & 779 & \\
\hline Interest on Operating Capital (5 \%) & & 122 & \\
\hline Total production cost & & 2,567 & 0.14 \\
\hline \multicolumn{4}{|l|}{ Fixed Costs } \\
\hline \multicolumn{4}{|l|}{ Cash overhead: } \\
\hline Insurance & & 100 & \\
\hline Taxes & & 100 & \\
\hline \multicolumn{4}{|l|}{ Non-cash overhead: } \\
\hline Land rent & & 500 & \\
\hline Other overhead & & 567 & \\
\hline Total fixed cost & & 1,267 & 0.07 \\
\hline Total Pre-Harvest Cost & & 3,834 & 0.21 \\
\hline \multicolumn{4}{|l|}{ Harvest and Marketing Costs } \\
\hline Picking and sales cost & & 5,662 & \\
\hline Total harvest and marketing cost & & 5,662 & 0.31 \\
\hline Total Cost & & 9,496 & 0.53 \\
\hline Gross Margin & & 18,851 & 1.04 \\
\hline Estimated Net Return & & 17,584 & 0.97 \\
\hline
\end{tabular}


Table 2. Sensitivity analysis, gross margin per acre.

\begin{tabular}{|c|c|c|c|c|c|c|}
\hline \multicolumn{2}{|c|}{ Yield (pounds/acre) } & \multicolumn{5}{|c|}{ Wholesale Price (dollars/pound) } \\
\hline & & 1.35 & 1.43 & 1.50 & 1.58 \\
\cline { 3 - 6 } & & & $(-10 \%)$ & $(-5 \%)$ & 1.65 \\
\hline 16,248 & $(-10 \%)$ & 13,706 & 15,006 & 16,143 & 17,443 \\
\hline 17,150 & $(-5 \%)$ & 14,924 & 16,296 & 17,496 & 18,868 \\
\hline 18,053 & (base) & 16,143 & 17,587 & 18,851 & 20,295 & 21,069 \\
\hline 18,956 & $(+5 \%)$ & 17,362 & 18,878 & 20,205 & 21,721 & 23,048 \\
\hline 19,858 & $(+10 \%)$ & 18,579 & 20,168 & 21,558 & 23,147 & 24,537 \\
\hline
\end{tabular}

Table 3. Sensitivity analysis, net returns per acre.

\begin{tabular}{|c|c|c|c|c|c|c|}
\hline \multicolumn{2}{|c|}{ Yield (pounds/acre) } & \multicolumn{4}{|c|}{ Wholesale Price (dollars/pound) } \\
\hline & & 1.35 & 1.43 & 1.50 & 1.58 \\
\hline & & $(-10 \%)$ & $(-5 \%)$ & (base) & $(+5 \%)$ \\
\hline 16,248 & $(-10 \%)$ & 12,439 & 13,739 & 14,876 & 16,176 \\
\hline 17,150 & $(-5 \%)$ & 13,657 & 15,029 & 16,229 & 17,601 \\
\hline 18,053 & (base) & 14,876 & 16,320 & 17,584 & 19,028 & 20,291 \\
\hline 18,956 & $(+5 \%)$ & 16,095 & 17,611 & 18,938 & 20,454 \\
\hline 19,858 & $(+10 \%)$ & 17,312 & 18,901 & 20,291 & 21,781 \\
\hline
\end{tabular}

